\title{
The Homiliary of Varlaam: Scientific Investigation of the Leather Bookbinding
}

\author{
CRISTINA CARSOTE ${ }^{1}$, ELENA BADEA ${ }^{2,3 *}$, IULIA-MARIA CANIOLA ${ }^{2}$, \\ SIMONA-MARIA PAUNESCU², MARIA-CRISTINA LUPAS ${ }^{2}$, \\ CLAUDIU SENDREA ${ }^{2}$, LUCRETIA MIU ${ }^{2}$ \\ ${ }^{1}$ National Museum of Romanian History, 12 Calea Victoriei, 030026, Bucharest, Romania \\ ${ }^{2}$ Advanced Research for Cultural Heritage Laboratory (ARCH Lab), National Research and Development Institute for \\ Textiles and Leather, Division Leather and Footwear Research Institute (INCDTP-ICPI), 93 Ion Minulescu Str., 031215, \\ Bucharest, Romania \\ ${ }^{3}$ University of Craiova, Faculty of Sciences, 107 I Calea Bucuresti, 200512, Craiova, Romania
}

\begin{abstract}
This paper presents a comprehensive deterioration profiling of the leather bookbinding of Cazania lui Vaarlam printed in 1643 and owned by the National Museum of Romanian Literature. A complex analytical approach encompassing spectroscopic techniques and thermal analysis methods was set up for the leather bookbinding to investigate collagen structural changes induced by ageing and assess the conservation condition of leather before the book restoration. The results' correlation at various structural levels brings out a detailed damage picture. The presence of gelatine was identified on the bookbinding surface through ATR-FTIR and MHT method while bulk / depth profile analysis such as micro DSC and NMR MOUSE indicated the decrease of the hydrothermal stability and collagen matrix rigidity mainly due to de-tanning.
\end{abstract}

Keywords: leather, bookbinding, gelatinisation, de-tanning, multiscale investigation, conservation

\section{Introduction}

The Cazania (Homiliary) of Varlaam, the first book in Moldavia printed in Romanian (1643), is a collection of homilies translated by Vaarlam, the Metropolitan of Moldavia. The book was commissioned by Prince Vasile Lupu of Moldavia and printed in Iasi, at the Three Hierarchs Monastery (Manastirea Trei Ierarhi) where the first printing press in Moldavia was set up in 1640. This comprehensive compilation translated from Slavonic into Romanian (pre limba Romeniasca) from the Seven Sacraments of the Church, the Answer to the Catechism of Calvin, together with the Law Code belonging to Vasile Lupu (Pravila lui Vasile Lupu), the first Moldavian law anthology, is known as the Romanian Book of Learning (Carte Romaneasca de Invatatura). It represents a linguistic monument that shows how vivid was the Romanian society in Moldavia in the seventeenth century, highlighting the road made by the Romanian people from the medieval to modern times. It was addressed to the entire Romanian nation everywhere (la toata semetia romaneasca de pretutindeni), as the foreword by Prince Vasile Lupu says. Consequently, a large number of copies of The Cazania of Varlaam or Varlaam's Homiliary spread rapidly in the neighbouring provinces inhabited by Romanian speakers despite its high price.

Apart of the merit of translating and collecting in the same volume a number of Greek and Slavonic religious manuscripts, Metropolitan Varlaam, who led the Moldovan Orthodox Church from 1632 until 1653, throughout the reign of Vasile Lupu (1634-1653), is considered one of the creators of the Romanian literary language.

The Cazania of Vaarlam comprises 54 homilies (biblical texts comments) on Sundays over the year and 21 homilies at the royal feasts and saints. It was printed in a print run of about 1,000 copies [1].

\footnotetext{
*email: elena.badea@unito.it
} 
In the preface, which the prince Vasile Lupu addresses to the Christian faithful, it is mentioned that this book in Romanian is a gift offered to the Romanian language, for God's praise and for the teaching and use of the Orthodox souls. The book played an essential rôle in the development of the Romanian language becoming in time the most read book in our old culture: generations of priests and teachers read these texts to believers in churches or to children at school. It had a wide circulation and a phenomenal impact in the Romanian intra-Carpathian provinces (Transylvania, Banat, Bihor, Maramures), where about 400 copies were found [2]. Moreover, no other worship book has not reached the number of reprints that the Cazania of Varlaam had, which in three centuries was reprinted entirely 14 times and in part 3 times, so totally 17 times. From the singular tradition of this unique book are also the well-known manuscripts as well as many untold ones that were copied by those who could not afford to buy a printed copy.

This paper presents a comprehensive analysis of the leather covers of one of the Cazania of Varlaam printed in 1643 and belonging to the National Museum of Romanian Literature. The analysis was occasioned by the restoration (rejuvenation) of the book. The physical-chemical study of the bookbinding was intended to assess various issues, from the identification and characterization of the materials and manufacturing process, to their damage assessment. Since the resistance of vegetable tanned leather in time depends to a large extent on the integrity of its collagen structure, a correct evaluation of the bookbinding health condition required the investigation of all structural levels of collagen, from the molecular level (triple helix) to the macroscopic level (collagen matrix). We have demonstrated that old/aged leather is a blend of tanned (chemically modified) collagen, untanned (chemically unmodified) collagen and gelatin [3-5]. In addition, the chemical and structural composition of leather may largely vary from one area to another across the cover. Frequently, historical leathers show zones with different degree and type of damage even within a limited area where deterioration may be superficial or partially/totally penetrated the inner structure. Deterioration can have a dynamic character as in case of environmental exposure, or can be isolated as for damage caused by handling, fire, floods, insects, etc. To cope with this complexity a multi-scale analytical protocol based on microdestructive (micro hot table method, micro differential scanning calorimetry) and non-destructive techniques (infrared spectrometry with attenuated total reflection and unilateral nuclear magnetic resonance) was set up [3-6]. This analytical approach can provide the necessary information to ensure optimal storage and exposure conditions and select the most suitable restoration treatments so that to ensure extending the bookbinding lifetime [7-10].

\section{Materials and methods Original bookbinding}

The bookbinding appears damaged with dry, shrunk and brittle looking as well as frequent cracking. Three micro-samples were taken for performing micro-destructive analysis from the most fragile areas, inherently exposed to material loss during normal use (i.e. edge, bookbinding spine, etc.). New chestnuttanned leather from goat hide was used for comparison. Extracts of chestnut wood are the most common ellagitannins used for vegetable tanning. Ellagitannins and gallotannins are the two subclasses of the hydrolysable tannins [11]. The new leather was prepared according to procedures inspired by traditional recipes at the National Research and Development Institute for Textile and Leather, Division Leather and Footwear Research, Bucharest (Romanian patent no.122098/ 2006: Piele naturala pentru legatorie carte de patrimoniu si procedeu de realizare a acesteia). The visual examination of the bookbinding indicated that the leather was most likely made from goat hide. The tannage, identified by ATR-FTIR, seems to have been a mix of hydrolysable and condensed tannins.

\section{Infrared spectrometry with attenuated total reflection (FTIR-ATR)}


The FTIR-ATR analyses were carried out in a non-destructive manner, directly on bookbinding, using a portable Alpha spectrometer (Bruker Optics) equipped with a Platinum ATR module. Spectra were recorded in the $4000-400 \mathrm{~cm}^{-1}$ spectral range with a $4 \mathrm{~cm}^{-1}$ resolution, using 32 scans. OPUS 7.0 software was used for processing and evaluating the spectra.

\section{Micro Hot Table (MHT) method}

The MHT method consists in the registration of the shrinking motion of few micro-fibres heated at a rate of $2^{\circ} \mathrm{C} \cdot \mathrm{min}^{-1}$ in the temperature range $(20-100){ }^{\circ} \mathrm{C}$. MHT measurements were carried out with a Linkam LTS120 micro heating plate (Linkam Scientific Instruments) equipped with an automatic heating rate adjustment system and a SMZ 745 Nikon stereomicroscope equipped with a Nikon D90 digital camera. The collagen shrinking is the intrinsic property of reducing their length up to a quarter of the original one when heated in an aqueous environment. It can be directly observed at the microscope while being registered for later evaluations by either an operator or image software [14-15]. The shrinking behaviour of collagen fibres when heated represents a fine measure of the hydrothermal stability of the collagen fibres and is currently evaluated based on few parameters: the temperature when the first shrinkage of an individual fibre is observed $\left(T_{\mathrm{f}}\right)$, the temperature when the simultaneous shrinkage in the fibre mass occurs $\left(T_{\mathrm{s}}\right)$ and the temperature when the last shrinkage of an individual fibre is observed $\left(T_{1}\right)$ [14]. $T_{\mathrm{s}}$ marks the beginning of the main shrinking interval $\Delta C$ when most fibres shrink simultaneously. The length of the main shrinkage interval $\Delta C$ depends on the degree of collagen fibre cohesion, while the length of the total shrinkage interval $\Delta T=T_{\mathrm{f}}-T_{\mathrm{f}}$ was related to the material structural heterogeneity [16].

\section{Micro Differential Scanning Calorimetry (micro DSC)}

Micro DSC measurements were carried out with a high-sensitivity SETARAM Micro-DSC III calorimeter using $850 \mu \mathrm{l}$ stainless steel (Hastelloy C) sample cells. Measurements were performed in the temperature range $(5$ to 95$){ }^{\circ} \mathrm{C}$ at $0.5 \mathrm{~K} \mathrm{~min}^{-1}$ heating rate. Micro-samples of about $2.0 \mathrm{mg}$ were suspended in $0.5 \mathrm{M}$ acetate buffer $(\mathrm{pH}=5.0)$ directly in the measure cell as previously reported [3, 5, 17]. Experimental DSC data acquired with the SETARAM SetSoft 2000 software were analysed using PeakFit 4.1 (Jandel Scientific) software. DSC multiple peaks of historical leather were deconvoluted using the PeakFit asymmetric Gaussian fit function to improve the fit of the asymmetry in the peaks.

\section{Unilateral Magnetic Resonance (NMR MOUSE)}

Non-invasive single-sided ${ }^{1} \mathrm{H}$ NMR measurements were performed at room temperature using an NMR MOUSE PM2 (Magritek GmbH) controlled by a Kea 2 spectrometer (Magritek GmbH) operating at $27 \mathrm{MHz}{ }^{1} \mathrm{H}$ resonance frequency as described earlier [4, 18, 19]. This system can measure proton relaxation times. Effective ${ }^{1} \mathrm{H}$ spin-spin relaxation $T_{2 \text { eff }}$ measurements have been measured using the Carr-Purcell-Meiboom-Gill (CPMG) pulse sequence with an echo-time (TE) of about $25 \mu \mathrm{s}$. The experimental CPMG curves were best analyzed by a combination of double exponential functions. The proton spin-lattice relaxation times $T_{1}$ were measured with a saturation-recovery pulse sequence using a Hahn-echo with an echo time of about $25 \mu$ s for detection. The analysis of the saturation recovery data was best performed with the help of a single exponential function.

\section{Results and discussions}

\section{Infrared spectrometry with attenuated total reflection (FTIR-ATR)}

The main absorption bands of collagen, namely amide $A\left(A_{A}\right): 3275 \mathrm{~cm}^{-1}\left(v_{N-H}\right)$, amide $B\left(A_{B}\right): 3065$ $\mathrm{cm}^{-1}\left(\delta_{\mathrm{NH} 2}\right.$ overtone), amide I $\left(\mathrm{A}_{\mathrm{I}}\right): 1630 \mathrm{~cm}^{-1}\left(v_{\mathrm{C}=\mathrm{O}}\right)$, amide II $\left(\mathrm{A}_{\mathrm{II}}\right): 1545 \mathrm{~cm}^{-1}\left(v_{\mathrm{CN}}\right.$ and $\left.\delta_{\mathrm{NH}}\right)$ and amide III (AII): $1232 \mathrm{~cm}^{-1}$ (in-plane $\delta \mathrm{NH}$ and $\mathrm{vCH}_{2}$ ) [20] were identified in all ATR-FTIR spectra collected from the historical bookbinding (Figure 1). As the infrared bands assigned to vegetable tannins are overlapping with those corresponding to collagen, the second derivative of the recorded ATR-FTIR 
spectra was calculated in the $(1750-700) \mathrm{cm}^{-1}$ spectral region to determine the type of tannins originally used for tanning (Figure 2). The spectral bands assigned to both hydrolysable and condensed tannins were identified in all recorded ATR-FTIR spectra (Figure 2). The bands common to both types of tannins were found at: $1606 \mathrm{~cm}^{-1}\left(v_{\mathrm{C}=\mathrm{C}}\right.$; aromatic ring), $1507 \mathrm{~cm}^{-1}\left(v_{\mathrm{C}=\mathrm{C}}\right.$; skeletal ring), $1445 \mathrm{~cm}^{-1}\left(v_{\mathrm{C}=\mathrm{C}}\right.$; aromatic ring), $1198 \mathrm{~cm}^{-1}$ ( $v_{\mathrm{C}-\mathrm{OH}}$; aromatic) and $1030 \mathrm{~cm}^{-1}$ ( $\beta-\mathrm{CH}$ deformation) [11-13]. It should be noted that the high intensity band at $1030 \mathrm{~cm}^{-1}$ indicates the presence of silicates dirt/dust adhering to the surface of leather (Figure 2). Hydrolysable tannins were identified through their typical bands occurring at 1721 $\mathrm{cm}^{-1}$ ( $v_{\mathrm{C}=\mathrm{O}}$; phenolic esters lactones or phenolic esters), $1322 \mathrm{~cm}^{-1}$ ( $v_{\mathrm{C}-\mathrm{O}}$; lactones), $1080 \mathrm{~cm}^{-1}\left(v^{\mathrm{s}} \mathrm{C}-\mathrm{O}-\mathrm{C}\right.$; aryl phenolic ester), $872 \mathrm{~cm}^{-1}$ ( $\gamma_{\mathrm{OH}}$ and $\gamma_{\mathrm{C}-\mathrm{H}}$; tetrasubsituted aromatic) and $758 \mathrm{~cm}^{-1}\left(v^{\mathrm{s}}\right.$ skeletal - sugar ring, breathing vibration) [11-13]. On the other hand, condensable tannins were identified through their typical bands occurring at $1282 \mathrm{~cm}^{-1}\left(v_{\mathrm{C}-\mathrm{O}}\right.$; pyran ring), $1159 \mathrm{~cm}^{-1}\left(v_{\mathrm{C}-\mathrm{O}-\mathrm{C}}^{\mathrm{s}}\right.$; cyclic ether $), 1110 \mathrm{~cm}^{-1}\left(v^{\text {as }}{ }_{\mathrm{C}-}\right.$ o-c; cyclic ether), $976 \mathrm{~cm}^{-1}$ and $842 \mathrm{~cm}^{-1}$ ( $\gamma_{\mathrm{C}-\mathrm{H}}$; tetrasubsituted aromatic) [11-13].

The main change in the collagen structure is indicated by the shape of the amide $\mathrm{I}\left(\mathrm{A}_{\mathrm{I}}\right)$ band: the amide I component at $1655 \mathrm{~cm}^{-1}$ indicates the presence of triple helical structure of collagen while the component at $1630 \mathrm{~cm}^{-1}$ is due to gelatin $[21,22]$. It is worth to mention that during denaturation of the triple helix, the dominant $1655 \mathrm{~cm}^{-1}$ band in the native collagen spectrum diminishes and the $1630 \mathrm{~cm}^{-1}$ band becomes relatively intensified.

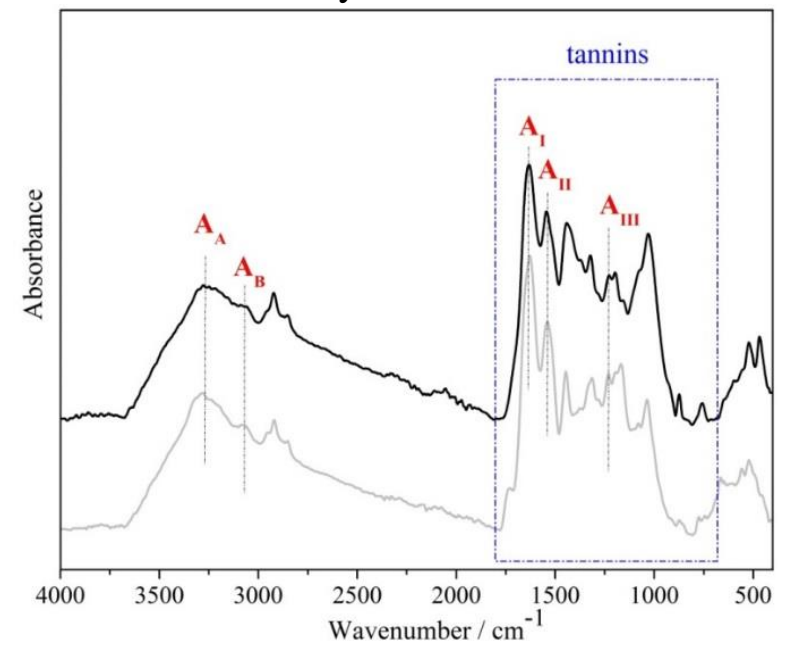

Figure 1. ATR-FTIR spectrum of the leather bookbinding (black line) as compared to that of a newly chestnuttanned goat leather (gray line). The main absorption bands of collagen $\left(\mathrm{A}_{\mathrm{A}}, \mathrm{A}_{\mathrm{B}}, \mathrm{A}_{\mathrm{I}}\right.$, $\mathrm{A}_{\text {II }}$ and $\left.\mathrm{A}_{\text {III }}\right)$, as well as the fingerprint region of tannins $(1750-700) \mathrm{cm}^{-1}$ are highlighted

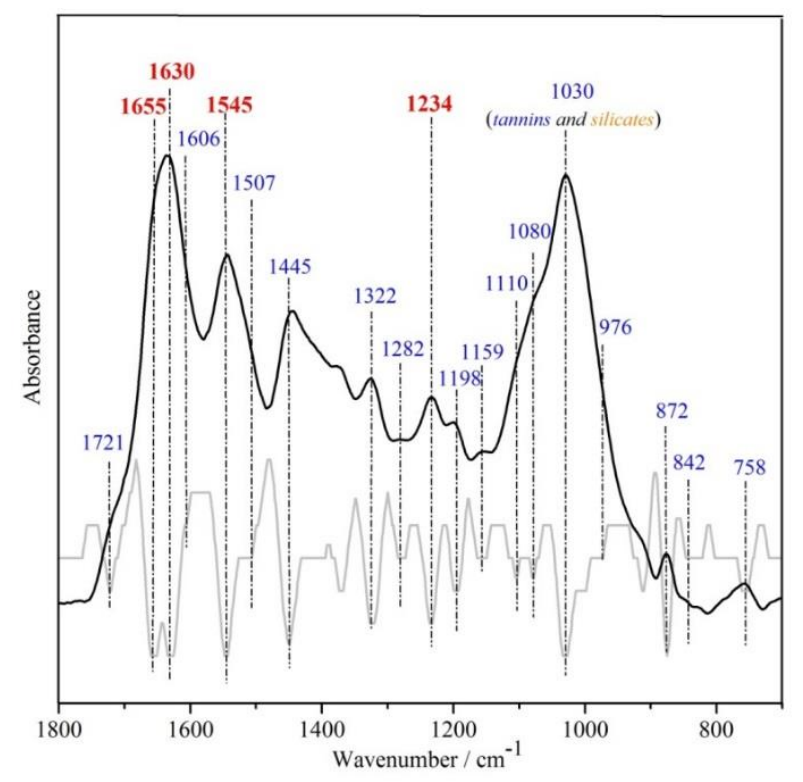

Figure 2. ATR-FTIR spectrum of the leather bookbinding (black line) in the $(1800-700) \mathrm{cm}^{-1}$ domain and its second derivative (gray line). The main absorption bands of collagen are highlighted in red, while those corresponding to tannins are evidenced in blue

Micro Hot Table (MHT) method 
The shrinking activity of the leather sub-samples taken from the bookbinding is shown in Figure 3 and compared to that of a new chestnut-tanned goat leather. The most important effect is the decrease of both $T_{\mathrm{f}}$ and $T_{\mathrm{s}}$ temperatures simultaneously with the increase of both $\Delta C$ and $\Delta T$ intervals. This behaviour indicates a significant drop of the hydrothermal stability [23]. In particular, the very low values of $T_{\mathrm{f}}$ indicate the presence of highly unstable collagen fractions, pre-gelatinised or even gelatinised. In addition, the widening of $\Delta C$ and $\Delta T$ intervals can be attributed to the loss of the microfibres cohesivity and increase of the structural heterogeneity, respectively.

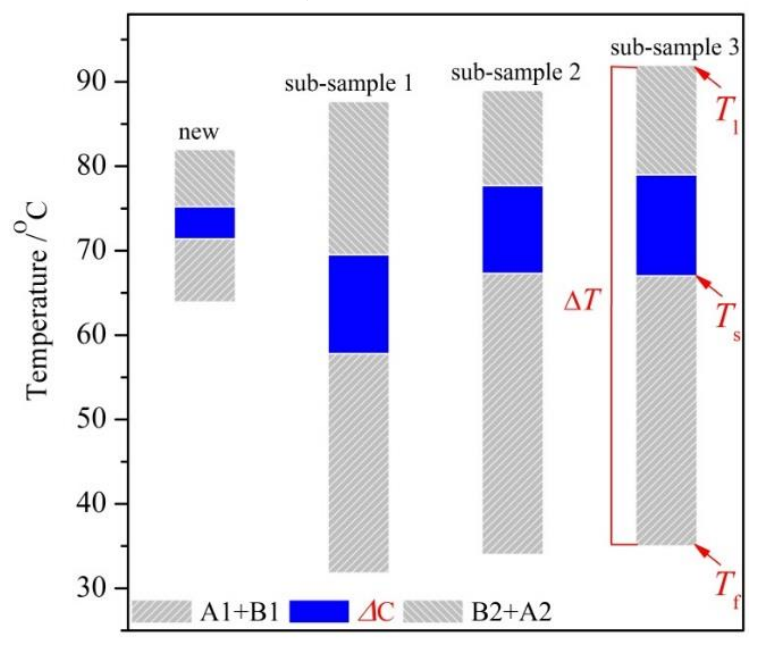

Figure 3. Stacked column charts displaying the shrinking intervals for collagen fibres for the three sub-samples taken from the bookbinding and new chestnut-tanned leather. The main shrinkage temperatures $\left(T_{\mathrm{f}}, T_{\mathrm{s}}\right.$ and $\left.T_{\mathrm{l}}\right)$ and intervals $(\Delta C$ and $\Delta T)$ are indicated

\section{Micro Differential Scanning Calorimetry (micro DSC)}

The transition of collagen macromolecules from their native triple helical structure into a random coiled structure via thermal unfolding (helix-to-coil transition) is revealed by micro DSC at a defined temperature, $T_{\max }$, which has been assumed as denaturation temperature of collagen fibrils according to a statistical process [24-26]. Besides the position $\left(T_{\max }\right)$ of the DSC peak, its height $\left(C_{p}^{e x} \max \right)$, width

$(\Delta T 1 / 2)$, area $(\Delta H)$ and symmetry provide valuable information about the denaturation process, and hence on the structural integrity of collagen [25-27]. In addition, the onset temperature $T_{\text {onset }}$ of the transition, calculated by using the tangent method, is explained by conformational changes occurring within the fibrils before the main denaturation transition $T_{\max }$, such as partial shrinkage of the fibrils [35]. The parameters of the denaturation process represent a measure of the collagen matrix stability while at the same time provide a measure of the distribution of molecular thermal stabilities [3, 17, 24, 25].

The parameters of thermal denaturation of collagen from the three investigated sub-samples are listed in Table 1 and compared to those measured for a new chestnut-tanned goat leather. From these data it follows that the hydrothermal stability of historical leather expressed as $T_{\max }$ is much lower than that of the new leather. This can be attributed with the utmost certainty to de-tanning, i.e. breaking down of the collagen-tannin bonding. We have recently showed that natural ageing occurs through the following key-steps: thermal destabilisation of chemically modified (tanned) collagen, de-tanning, thermal destabilisation of chemically unmodified (fully de-tanned) collagen, gelatinisation and irreversible denaturation [3,5]. In addition, we identified these various collagen populations based on their hydrothermal stability: leather-like population shows denaturation in the interval $(65-85){ }^{\circ} \mathrm{C}$; parchment-like population shows denaturation in the interval $(45-65){ }^{\circ} \mathrm{C}$; gelatine-like population shows thermal transition at $T \leq 45^{\circ} \mathrm{C}$ [5]. From data in Table 1, it appears that historical leather shows a boundary behaviour between leather-like and parchment-like structures. This is likely due to the collagen-tannin complex breakdown (de-tanning) occurring over time [28]. Moreover, the enthalpic values are much lower compared with that of the new leather. This is likely due to the collagen content decrease over time as a result of its irreversible denaturation induced by deterioration. In fact, severely deteriorated collagen that does not contribute to the denaturational change in enthalpy accumulates in 
the leather over time, resulting in a decrease of the overall denaturation enthalpy [5]. Additional information on the structural heterogeneity of historical leather comes from the half-width of the overall DSC peak, $\Delta T_{1 / 2}$ (Table 1). It is apparent from these data and from Figures 4 that the shape of the overall DSC peak reflects rather high structural heterogeneity due to the presence of multiple collagen populations. For example, in the sub-sample 3 (Figure 4) three collagen populations with distinct thermal stability coexist.

\section{Table 1}

Parameters of thermal denaturation of collagen in the three sub-samples taken from the bookbinding compared to those measured for a new chestnut-tanned goat leather.

\begin{tabular}{cccccc}
\hline Samples & $T_{\text {onset }} /{ }^{\circ} \mathrm{C}$ & $T_{\max } /{ }^{\circ} \mathrm{C}$ & $\Delta H / \mathrm{J} \cdot \mathrm{g}^{-1}$ & $\Delta T_{1 / 2} /{ }^{\circ} \mathrm{C}$ & $C_{p, \max }^{e x} / \mathrm{J}^{-1} \cdot \mathrm{g}^{-1}$ \\
\hline new leather & $66.1 \pm 0.5$ & $70.4 \pm 1.1$ & $23.8 \pm 2.5$ & $4.1 \pm 0.2$ & $4.3 \pm 0.2$ \\
\hline sub-sample 1 & 55.0 & 60.2 & 7.4 & 6.7 & 0.98 \\
sub-sample 2 & 61.7 & 65.3 & 6.9 & 5.2 & 1.09 \\
sub-sample 3 & 59.9 & 64.2 & 6.5 & 4.8 & 1.26 \\
\hline
\end{tabular}
Uncertainty is the standard deviation.
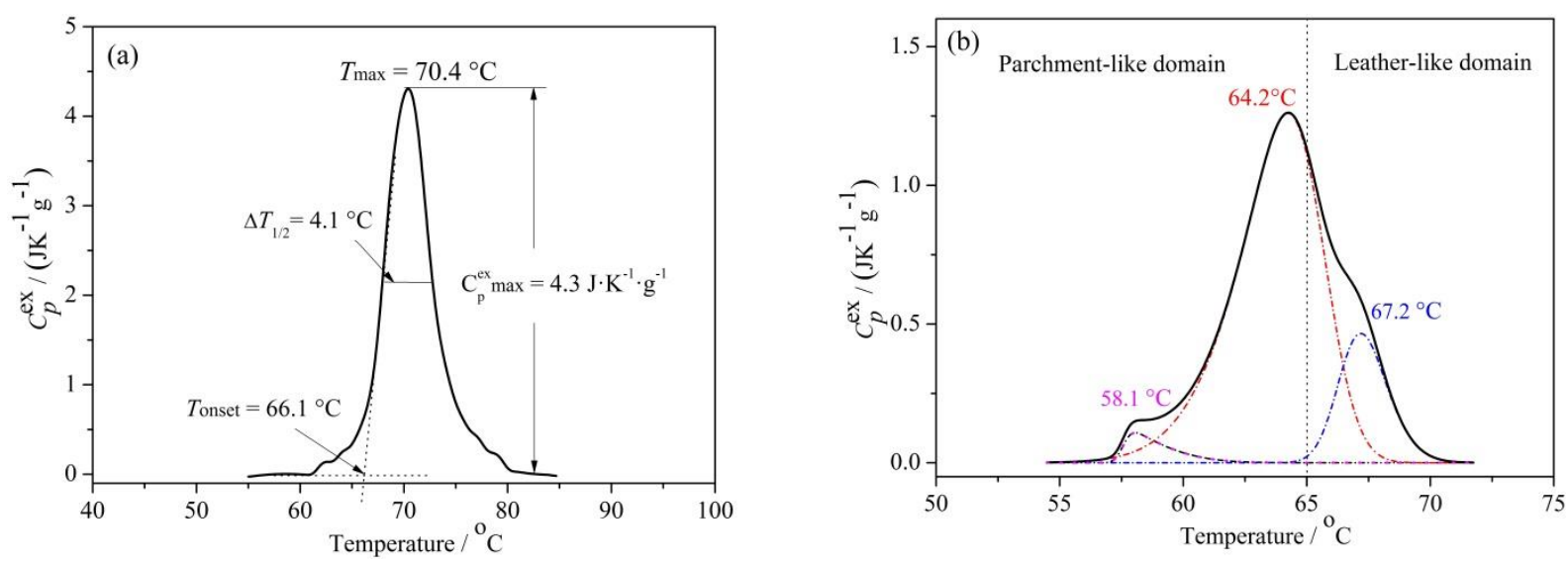

Figure 4. (a) Typical DSC denaturation peak associated with thermal denaturation of fully hydrated collagen fibrils from a new goat leather tanned with chestnut extract. $T_{\text {onset }}\left({ }^{\circ} \mathrm{C}\right)$ is defined by the intersection of a line tangent to the steepest section of the leading edge and the baseline of the thermogram. $T_{\max }\left({ }^{\circ} \mathrm{C}\right)$ is the temperature of maximum heat flow. Enthalpy of thermal denaturation, $\Delta H(\mathrm{~J} / \mathrm{g})$, is the area under the endothermic peak. $\Delta T_{1 / 2}\left({ }^{\circ} \mathrm{C}\right)$ is the full width at half maximum of the endothermic peak. (b) Deconvolution of DSC denaturation multi-component peaks for sub-sample 3 of the investigated bookbinding illustrating the distribution of collagen populations with distinct thermal stability and their allocation to the leather-like domain and parchment-like domain.

\section{Unilateral Magnetic Resonance (NMR MOUSE)}

The interaction of collagen with water at specific levels of its hierarchical organisation within a material relates with the material stability. A solid state NMR experiment with degraded parchment revealed that ageing decreases the water content in a parchment sample due to partial hydrolysis of peptide bonds in collagen [29]. The hydrolysed collagen is considered a degraded gelatine, with a mixture of smaller molecular weight polypeptides. Moreover, historical leather is a complex blend of collagen with various degrees of tanning, fully de-tanned collagen and gelatine. We have previously showed that relaxation times may provide information about the tanning technique and ageing behaviour $[4,16,19,30]$. For example, from a $T_{1}$ experiment on parchment performed with a single-sided NMR sensor, Badea et al. [24] proposed that the gelatinisation process disorganizes the collagen structure and leads to shorter $T_{1}$ values, while the hydrolytic process produces longer $T_{1}$ values. From the relaxometric 
data listed in Table 2, we could infer a decrease of the collagen matrix organisation due to de-tanning as suggested by collagen fibres shrinking behaviour and collagen denaturation indices leading to gelatinisation, as indicated by ATR-FTIR analysis. In addition, the increase of the values of both components of the spin-spin relaxation time $T_{2}$, attributed to collagen-water interaction at a freer (the long component) and more restricted (the short component) level, could be attributed to a decrease of the collagen matrix rigidity due to a loss of cross-links between collagen and tannin as well to a loss of molecular cross-linking via water molecules [29,31]. This indicates that the leather becomes less rigid, and the molecules become more mobile as a result of the de-tanning process.

\section{Table 2}

Relaxometric parameters for the historical leather compared with those measured for new vegetable tanned leather, parchment and gelatine.

\begin{tabular}{cccc}
\hline Colagen-based material & $T_{1}(\mathrm{~ms})$ & $T_{\text {2eff_long }}(\mathrm{ms})$ & T $_{\text {2ff_short }}(\mathrm{ms})$ \\
\hline chestnut-tanned goat leather & $24.9 \pm 0.15$ & $2.3 \pm 0.12$ & $0.26 \pm 0.01$ \\
parchment & $50.03 \pm 0.29$ & $0.72 \pm 0.04$ & $0.16 \pm 0.01$ \\
gelatine & $77.09 \pm 0.88$ & $1.29 \pm 0.18$ & $0.18 \pm 0.01$ \\
historical bookbinding & $9.7 \pm 1.3$ & $5.4 \pm 0.6$ & $1.3 \pm 0.3$ \\
\hline
\end{tabular}

\section{Conclusions}

Deterioration of the historical leather bookbinding was studying using ATR-FTIR, MHT method, micro DSC and NMR MOUSE. The deterioration assessment was performed based on the variation of its physical-chemical parameters in comparison with new collagen based materials. The molecular composition analysed by ATR-FTIR indicated mixed vegetable tanning (hydrolysable and condensed tannins) and the presence of gelatine. The fibre assessment by MHT method confirmed the presence of gelatine and evidenced a high degree of structural heterogeneity accompanied by a decrease of the hydrothermal stability. The denaturation parameters determined by micro-DSC also indicated the low hydrothermal stability of the material as well as the loss of the collagen content as a result of its irreversible denaturation induced by deterioration. In addition, by DSC denaturation peak deconvolution, a boundary behaviour between leather-like and parchment-like structures was revealed. NMR-MOUSE depth profiles confirmed the decrease of the collagen matrix disorganisation and through de-tanning and gelatinisation.

Funding: This work was supported by a grant of the Romanian Ministry of Research and Innovation through the Nucleu Programme, project no. PN 1917 05 01, grant number 4N/2019.

Acknowledgement: The authors would like to thank the National Museum of Romanian Literature for offering us the opportunity to investigate the leather bookbinding from Cazania of Varlaam. The cost is funded by the Minister of Research and Innovation through the Program 1 - Development of the National Research and Development System, Subprogram 1.2 - Institutional Performance - RDI excellence funding projects, Contract no. 6PFE/16.10.2018.

\section{References}

1.MURESANU, F., Cazania lui Varlaam, 1643 - 1943: Prezentare in imagini (1944), E.R.A.N., Editor Prof. Dr. Emil Hatieganu, Cluj, 1944.

2.DUDAS, F. Cazania lui Varlaam in Transilvania: studiu istoric si bibliologic, Editura Lumina, Oradea, 2004.

3.CARSOTE, C., BADEA, E., MIU, L., DELLA GATTA, G., J.Therm. Anal.Cal., 124, 2016, p.1255-1266.

4.BADEA, E., SENDREA, C., CARSOTE, C., ADAMS, A., BLUMICH, B., IOVU, H., Microchem. J., 129, 2016, p.158-165.

5.CARSOTE, C., BADEA, E., Herit. Sci., in-press.

6.CARSOTE, C., BUDRUGEAC, P., DECHEVA, R., HARAlAMPIEV, N. S., MIU, L., BADEA, E., Rev. Roum. Chim., 59, (6-7), 2014, 429 
7.CARSOTE, C., KOVARI, L., ALBU, C., HADIMBU, E., BADEA, E., MIU, L., DUMITRESCU, G., Leather and Footwear Journal, 18, no. 4, 2018, p. 307-320.

8.CARSOTE, C., BALTA, Z.I., BADEA, E., MIU, L., Materials in the Tetraevangelion of Nicodemus from Tismana under the magnifying lens of modern analysis techniques, In: The Tetraevangelion of Saint Pious Nicodemus of Tismana, Ed. Magic Print, Onesti, 2018, p. 72-122.

9.CARSOTE, C., BADEA, E., I segreti della pergamena del testamento di Marco Polo, In IL TESTAMENTO DI MARCO POLO - Il documento, la storia, il contest, Ed. Tiziana Plebani, Realizzata con il sostegno di Scrinium s.p.a, Italy, 2019, p. 169-186.

10.CARSOTE, C., BADEA, E., BALTA, Z.I., PETROVICIU, I., MIU, L., Unveiling the secrets of Codex Altemberger: About the materials and techniques used In: Codex Altemberger - The first legal code of the Transylvanian Saxons in Sibiu, Ed. National Museum of Romanian History, Bucharest, 2019, p. 120-142.

11.FALCAO, L., ARAÚJO, M.E.M., Molecules, 23, no. 5, 2018, p. 1081.

12.FALCAO, L., ARAÚJO, M.E.M., J. Cult. Herit., 14, 2013, p. 499-508.

13.FALCAO, L., ARAÚJO, M.E.M., Vib. Spectrosc., 74, 2014, p. 98-103.

14.LARSEN, R., VEST, M., NIELSEN, K., J.Soc.Leather. Technol. Chem., 77, 1993, p.151-156.

15.MIU, O. A., BADEA, E., CARSOTE, C., CIOBANU, S., Proceedings Book of the $5^{\text {th }}$ International Conference on Advanced Materials and Systems, Editura Certex, Bucharest, 2014, p. 539-542.

16.SENDREA, C., CARSOTE, C., RADU, M., BADEA, E., MIU, L., Rev. Chim. (Bucharest), 68, (7), 2017, 1535

17.BADEA, E., DELLA GATTA, G., BUDRUGEAC, P., J. Therm. Anal. Calorim., 104, no .2, 2011, p. 495-506.

18.SENDREA, C., BADEA, E., ADAMS, A., Rev. Chim. (Bucharest), 68, (8), 2017, 1780

19.BADEA, E., CARSOTE, C., HADIMBU, E., SENDREA, C., LUPAS M. C., Herit. Sci., in-press.

20.BARTH, A., Biochim. Biophys. Acta. 1767, 2007, p.1073-1101.

21.VICHI, A., ELIAZYAN, G.,KAZARIAN, S.G., ACS Omega, 3, 2018, p. 7150-7157.

2.SENDREA, C., CARSOTE, C., BADEA, E., ADAMS, A., NICULESCU, M., IOVU, H.,U.P.B. Sci. Bull., Series B, 78, no.3, 2016, p. 27-38.

23.BUDRUGEAC, P., CARSOTE, C., MIU, L., J. Therm. Anal. Calorim, 127, 2017, p. 765-762.

24.BADEA, E., MIU, L., BUDRUGEAC, P., GIURGINCA, M., MASIC, A., BADEA, N., DELLA GATTA, G., J. Therm. Anal. Calorim., 91, 2008, p.17-27.

25.BADEA, E., DElla GATTA, G., USACHEVA, T., Polym. Degrad. Stab., 97, 2011, p. 346-353.

26.WEIR, C.E., J. Am. Leather. Chem. Assoc., 44, 1949, p. 108-40.

27.MILES, C.A., BAILEY, A.J., Proc. Indian. Acad. Sci. (Chem. ScL), 111, no. 1, 1999, p.71-80.

28.SEBESTYEN, Z., CZEGENY, Z., BADEA, E., CARSOTE, C., SENDREA, C., BARTA-RAJNAI, E., JANOS, B., MIU, L., JAKAB, E., J. Anal. Appl. Pyrol. 115, 2015, p. 419-427.

29.ALIEV., A.E., Biopolymers, 77, no. 4, 2005, p. 230-245.

30.SENDREA, C., BADEA, E., STANCULESCU, I., MIU, L., IOVU, H., Leather and Footwear Journal, 15, no. 3, 2015, p. 139-150.

31.ZHU, L., DEL FEDERICO, E., ILOTT, A. J., KLOKKERNES, T., KEHLET, C., JERSCHOW, A., Anal. Chem., 87, no.7, 2015, p. 3820-3825.

Manuscipt received: 06.07.2019 